\title{
PEMBENTUKAN PERATURAN DAERAH, DAN PENERAPAN SANKSI PIDANA SERTA PROBLEMATIKANYA
}

\author{
(Establishment of Regional Regulation and Enforcement of Criminal Sanctions and Its Difficulties)
}

\author{
Suharyo \\ Pusat Penelitian dan Pengembangan Sistem Hukum Nasional \\ Badan Pembinaan Hukum Nasional \\ Email: massuharyo@ymail.com
}

Naskah diterima: 29 September 2015; revisi: 26 November 2015; disetujui: 2 Desember 2015

\begin{abstract}
Abstrak
Era Otonomi Daerah secara nyata, jelas dan tegas dilaksanakan di Indonesia sejak adanya reformasi di segala bidang, hal ini merupakan perwujudan pelaksanaan demokrasi lokal diseluruh Indonesia, dengan berbagai kemandirian dalam konteks Negara Kesatuan Republik Indonesia (NKRI) yang tetap pada koridor peraturan perundang-undangan yang berlaku. Dalam melaksanakan otonomi daerah di wilayahnya tiap daerah memiliki kewenangan pembentukan Peraturan Daerah (Perda), selain mengatur hubungan sosial kemasyarakatan yang berisi kewajiban dan larangan, Perda acapkali dilengkapi dengan sanksi pidana. Berangkat dari hal tersebut penelitian ini bermaksud mencari bentuk pembentukan Perda yang ideal dan aspiratif dan melihat efektivitas penerapan sanksi pidana dalam produk Perda di tengah masyarakat. Dengan menggunakan metode yuridis normatif dapat disimpulkan bahwa diperlukan pelibatan warga masyarakat mulai dari pembentukan Raperda termasuk dalam pembahasan penetapan sanksi pidana. Terhadap perumusan sanksi pidana di dalam Perda harus menghindari adanya pengaturan pidana kurungan. Oleh sebab itu guna efektifitas pelaksanaan Perda diperlukan sosialisasi yang intensif dengan cara-cara kekeluargaan dan perlunya strategi persuasif, preventif, akomodatif, dan simpatik dalam penegakan Perda.
\end{abstract}

Kata Kunci: perda, penerapan sanksi pidana

\section{Abstract}

The Regional Autonomy era is tangibly, clearly and firmly held in Indonesia since reformasi period (reform) in all fields, this is the manifestation of the implementation of local democracy throughout Indonesia, with a variety of self-reliance in the context of the Unitary State of the Republic of Indonesia (NKRI), which remained at the corridor of applicable law. In implementing regional autonomy, each region has the authority to establish the Regional Regulation (Perda) that regulates social relationships which isstated obligations and prohibition. It is also often comes with criminal sanctions. Toward those facts, this research intends to seek the ideal form to establish regional regulation and to observe the effectiveness ofenforcing criminal sanctions in society as a product of regional regulation. Using normative-jurist method can be concluded that it needs the involvement of citizens in making draft regional regulations (Raperda) and also in establishing criminal sanctions. While developing a formula for criminal sanctions in regional regulation, it should avoid an imprisonment. Therefore, for the implementation of the regional regulation to be effective, there should be an intensive dissemination in relationship way and the need for persuasive strategies, preventive, accommodating and sympathetic in enforcing the regional regulation.

Keywords: regional regulation, enforcement of criminal sanction 


\section{A. Pendahuluan}

Produk Peraturan daerah (Perda) ${ }^{1}$, merupakan kewenangan Pemerintah Daerah (Pemda) dan Dewan Perwakilan Rakyat Daerah (DPRD). Utamanya sejak pelaksanaan Otonomi daerah melalui Undang-undang Nomor 5 tahun 1974 Tentang Pokok-pokok Pemerintahan di Daerah, Undang-Undang Nomor 22 Tahun 1999 Tentang Pemerintahan Daerah jo Undangundang Nomor 32 Tahun 2004, jo UndangUndang Nomor 23 Tahun 2014.

Di samping itu, khusus untuk Daerah Istimewa Yogyakarta sesuai Undang-Undang Nomor 13 Tahun 2012 Tentang Keistimewaan Daerah Istimewa Yogyakarta. Untuk Provinsi Aceh, sesuai dengan Undang-Undang Nomor
11 Tahun 2006 Tentang Pemerintahan Aceh². Penamaan Perda, sedikit berbeda menjadi Peraturan Daerah Khusus (Perdasus). Untuk Provinsi Papua, termasuk Provinsi Papua Barat sesuai Undang-Undang Nomor 21 Tahun 2001 Tentang Otonomi Khusus Bagi Provinsi Papua. ${ }^{3}$

Era Otonomi Daerah yang secara nyata, jelas dan tegas dilaksanakan di Indonesia sejak adanya reformasi di segala bidang, diawali dari eksistensi Undang-Undang Nomor 22 Tahun 1999 Tentang Pemerintahan Daerah. Otonomi daerah sebagai perwujudan pelaksanaan demokrasi lokal diseluruh Indonesia, dengan berbagai kemandirian dalam konteks Negara Kesatuan Republik Indonesia (NKRI), pada gilirannya mengacu pada seluruh peraturan perundang-undangan yang berlaku.

Lihat Pasal 236 Undang-Undang Nomor 23 Tahun 2014 (LN No.244 TLN No.5587 Tahun 2014).

(1) Untuk menyelenggarakan otonomi daerah dan tugas pembantuan, daerah membentuk Perda.

(2) Perda sebagaimana dimaksud pada ayat (1) dibentuk oleh DPRD dengan persetujuan bersama Kepala Daerah.

(3) Perda sebagaimana dimaksud pada ayat (1) memuat materi muatan:

a. Penyelenggaraan Otonomi Daerah dan Tugas Pembantuan; dan

b. Penjabaran lebih lanjut ketentuan peraturan perundang-undangan yang lebih tinggi.

(4) Selain materi muatan sebagaimana dimaksud pada ayat (3) Perda dapat memuat materi muatan lokal sesuai dengan ketentuan peraturan perundang-undangan.

2 Qanun Aceh adalah peraturan perundang-undangan sejenis Peraturan Daerah Provinsi yang mengatur penyelenggaraan pemerintahan dan kehidupan masyarakat Aceh. Lihat Pasal 1 angka 21 Undang-Undang Nomor 11 Tahun 2006. Qanun Kabupaten/Kota adalah peraturan perundang-undangan sejenis peraturan daerah kabupaten/kota yang mengatur penyelenggaraan pemerintahan dan kehidupan masyarakat Aceh. Lihat pasal 1 angka 22 Undang-undang Nomor 11 Tahun 2006. (LN No.62 TLN No.4633 Tahun 2006).

Materi muatan Qanun mengandung asas:
a. Pengayoman;
b. Kemanusiaan;
c. Kebangsaan
d. Kekeluargaan
e. Keanekaragaman
f. Keadilan
g. Nondiskriminasi
h. Kebersamaan kedudukan dalam hukum dan pemerintahan.
i. Ketertiban dan kepastian hukum; dan/atau
j. Keseimbangan, keserasian, kesetaraan, dan keselarasan.

Selain asas sebagaimana dimaksud pada ayat (1), Qanun dapat memuat asas lain sesuai dengan materi muatan Qanun yang bersangkutan. Lihat pasal 237 ayat (1) dan ayat (2) Undang-Undang Nomor 11 Tahun 2006.

Lihat Undang-Undang Nomor 21 Tahun 2001 tentang Otonomi Khusus Bagi Provinsi Papua. (LN No.135 TLN No.4151 Tahun 2001). Pada pasal 29 (1) Perdasus dibuat dan ditetapkan oleh DPRP bersama-sama Gubernur dengan pertimbangan dan persetujuan MRP. (2). Perdasi dibuat dan ditetapkan oleh DPRP bersama-sama Gubernur 
Sesuai dinamika ketatanegaraan yang terus berkembang, Undang-undang Nomor 22 Tahun 1999, kemudian dirubah menjadi Undang-Undang Nomor 32 Tahun 2004 Tentang Pemerintahan Daerah, sekarang UndangUndang Nomor 23 Tahun 2014. Dan otonomi daerah memberikan keleluasaan yang besar pada daerah untuk mengatur rumah tangganya sendiri. Perubahan Undang-undang Dasar 1945, yang diantaranya dalam aspek pembentukan peraturan perundang-undangan dilaksanakan melalui Undang-Undang Nomor 20 Tahun 2004 jo Undang-Undang Nomor 12 Tahun 2011, memberikan peluang bagi daerah untuk membentuk Perda.

Perda dibentuk oleh Dewan Perwakilan Rakyat Daerah (DPRD) yang dibahas bersamasama dengan Kepala Daerah untuk memperoleh persetujuan bersama. Dalam konteks ini, pembahasan dan persetujuan bersama atas Perda yang dibentuk itu berlangsung di DPRD. Pembentukan Perda tidaklah begitu saja, melainkan diawali dengan proses Penyusunan Rancangan Perda. Karena itu, kualitas suatu Perda dan pengambilan keputusan atas Rancangan Perda menjadi Perda sangat ditentukan oleh bagaimana dan dengan cara bagaimana Rancangan Perda itu disusun. Disinilah dibutuhkan kearifan bersama antara Pemerintah Daerah, DPRD, dan masyarakat dalam membuat Perda ${ }^{4}$.

Adanya perubahan Undang-Undang Nomor 32 Tahun 2004 menjadi Undang-Undang Nomor 23 Tahun 2014, secara implisit tidak merubah dan tidak membatasi kewenangan daerah dalam membentuk Perda. Dapat dipastikan masing- masing daerah, termasuk daerah pemekaran, baik yang mempunyai otonomi khusus di Aceh dan Papua, serta daerah Istimewa Yogyakarta, dan DKI Jakarta berlomba untuk membuat Perda.

Dalam negara hukum yang demokratis, pembentukan Perda sebagaimana ditegaskan dan diharuskan dalam peraturan perundangundangan pemerintahan daerah, diperlukan dan diwajibkan adanya kerjasama antara DPRD dengan Pemerintah daerah, serta partisipasi aktif warga masyarakat di daerah. Suatu partisipasi warga masyarakat dalam produk proses pembuatan Perda, dapat berlangsung sesuai yang diharapkan ataupun warga masyarakat justru mereka tidak diberi tahu bahkan tidak didengar dan direspon dalam menyikapi rencana pembuatan Perda.

Suatu dinamika yang dapat terjadi, berkenaan pembuatan Perda adalah keterkaitan antara interaksi politik lokal dengan teknis pembuatan peraturan perundang-undangan, yang batasannya tidak boleh bertentangan dengan UUD 1945, serta peraturan perundangundangan diatasnya. Keterbatasan sumber daya manusia (SDM) anggota DPRD, bahkan jajaran Pemerintah Daerah sendiri, dapat menghasilkan Perda yang bermasalah. Implikasi dari Perda yang bermasalah dapat di gugat oleh warga masyarakat, serta dapat dibatalkan oleh pemerintah pusat.

Sebagaimana ditegaskan dalam UndangUndang Dasar 1945, Indonesia adalah negara hukum. ${ }^{5}$ Edie Toet Hendratno mengutip Padmo Wahyono yang menyatakan, negara hukum adalah negara yang menjamin hak-hak

Jazim Hamidi dan Kemilau Mutik. Legislative Drafting (Yogyakarta: Tatasmedia, 2011), hlm. 5.

Edie Toet Hendratno. Negara Kesatuan, Desentralisasi, dan Federalisme (Yogyakarta, Graha Ilmu 2009), hlm. 117. 
asasi. Negara hukum merupakan pengertian yang ideal sekali dan merupakan syarat untuk (conditio sine quanon). Negara hukum dianggap sebagai pelengkap dari negara demokrasi. Produk Perda yang di dalamnya mengatur perizinan dan/atau kewajiban warga masyarakat dalam konteks tertentu, utamanya di samping untuk terwujudnya keamanan dan ketertiban umum, dan keserasian serta keberhasilan, juga mendukung pemasukan uang bagi pembangunan daerah. Pada gilirannya, dalam Perda-perda tersebut, dicantumkan pasal-pasal tentang kewajiban dan larangan, yang berujung pada sanksi-sanksi pidana.

Perkembangan hukum pidana ternyata semakin banyak digunakan dan diandalkan dalam rangka mengatur dan mentertibkan masyarakat melalui peraturan perundangundangan. Dinamika hukum dapat terlihat dari adanya kebijakan penggunaan sanksi pidana melalui pencantuman bab tentang "ketentuan sanksi pidana" pada bagian akhir sebagian besar produk peraturan perundang-undangan di Indonesia. Pencantuman bab tentang ketentuan sanksi pidana tersebut tidak hanya terlihat dalam produk peraturan perundangundangan pusat yaitu Undang-undang, melainkan dapat terlihat pula dalam produk peraturan perundang-undangan lokal yang berbentuk "Perda". 6

Implementasi penegakan hukum terhadap Perda, tidak selamanya berjalan sesuai yang dicantumkan dalam produk Perda itu sendiri. Pemerintah Daerah tidak selamanya konsisten menegakkan Perda. Pembiaran terhadap pelanggaran Perda oleh warga masyarakat, bahkan penyimpangan-penyimpangan yang dilakukan elit birokrasi dan politik di daerah banyak terjadi. Khusus upaya penegakan Perda yang melibatkan pelanggaran oleh kelompok besar warga masyarakat, Satuan Polisi Pamong Praja, justru tidak berdaya. Yang pada gilirannya pasti meminta bantuan pada Polri ${ }^{7}$, bahkan meminta perkuatan TNI.

Berangkat dari latar belakang di atas penelitian ini mencoba menemukan bagaimana pembentukan Perda yang ideal dan aspiratif dan melihat efektivitas penerapan sanksi pidana dalam produk Perda di tengah masyarakat.

\section{B. Metode Penelitian}

Dalam penulisan ilmiah berjudul "Pembentukan Perda dan Penerapan Sanksi Pidana Serta Problematikanya", metode penelitian hukum yang dipakai adalah yuridis normatif, yang merupakan penelitian kepustakaan (library research). Dalam konteks penelitian kepustakaan dilakukan dengan mengumpulkan data dari surat kabar peraturan perundang-undangan dan berbagai materi sekunder pilihan serta menganalisis secara mendalam dan komprehensif. Pendekatan normatif sangat selaras guna menganalisis produk pembentukan Perda, penerapan sanksi 
pidana, di tengah problematikanya dalam negara hukum yang demokratis.

\section{Pembahasan}

Pembentukan hukum akan mengikuti struktur sosial politik dari masing-masing negara. Bagi negara yang menganut konfigurasi politik otoriter, maka pembentukan hukumnya akan memperlihatkan ciri yang otoritarian juga. Manakala proses pembentukan hukum (legislasi) tersebut ditempatkan dalam konteks struktur sosial politik dari negara demokrasi, niscayanya didalamnya akan terjadi kompromi dari konflik-konflik nilai dan kepentingan yang berbeda-beda dalam masyarakat. ${ }^{9}$

Menurut Satjipto Rahardjo ${ }^{10}$, dapat diketengahkan bahwa proses pembentukan hukum (legislasi) merupakan proses yang relatif sangat penting sebagaimana relatif pentingnya melihat proses implementasi dan enforcement darihukum itu sendiri. Proses-proses yang terjadi dalam pembentukan hukum bagaimanapun juga akan ikut mempengaruhi proses implementasi dan penegakan hukumnya. Kekeliruan dalam proses pembentukan hukum bisa berakibat fatal, sebab dari proses pembentukan hukum yang keliru tersebut bisa melahirkan produk hukum yang bersifat kriminogen dalam pergaulan bersama masyarakat.

Jeremy Benthan sebagaimana dikutip oleh A. Hamid S Atamimi mengemukakan, pembentukan peraturan perundang-undangan harus menghindari antara lain: Arti ganda; Kekaburan; Terlalu luas; Ketidaktepatan ungkapan. ${ }^{11}$
Dalam Undang-undang Dasar 45 ditegaskan pada Pasal 20, diantaranya:

(1) Dewan Perwakilan Rakyat memegang kekuasaan membentuk undang-undang

(2) Setiap rancangan undang-undang dibahas oleh Dewan Perwakilan Rakyat dan Presiden untuk mendapat persetujuan bersama

(3) Jika rancangan undang-undang itu tidak mendapat persetujuan bersama, rancangan undang-undang itu, tidak boleh diajukan lagi dalam persidangan Dewan Perwakilan Rakyat masa itu

Walaupun tidak termasuk sebagai produk hukum yang pembentukannya dalam domain Undang-Undang Nomor 12 Tahun 2011 tentang Pembentukan Peraturan Perundang-Undangan, Undang-Undang Dasar 1945 merupakan produk konstitusi yang tertulis dan produk hukum yang tertinggi di Indonesia dan sebagai dasar hukum setiap pembentukan produk hukum dibawahnya.

Undang-Undang Nomor 12 Tahun 2011 tentang Pembentukan Peraturan Perundangundangan, pada pasal 1 ayat 1 menyebutkan: "Pembentukan peraturan perundang-undangan adalah pembuatan peraturan perundangundanganyangmencakuptahapan perencanaan, penyusunan, pembahasan, pengesahan atau penetapan, dan pengundangannya".

Di samping teori pembentukan peraturan perundang-undangan, juga didukung oleh teori penegakan hukum. Menurut Soerjono Soekanto, ketergantungan pada kaitan yang serasi dari paling tidak empat faktor, yaitu: Baik buruknya hukum yang berlaku; Baik buruknya

Anis Ibrahim. Legislasi dan Demokrasi. Interaksi dan Konfigurasi Politik Hukum Dalam Pembentukan Hukum di Daerah (Malang: In Trans Publishing, 2008) hlm. 104.

10 Satjipto Rahardjo. Sisi-sisi Lain Hukum di Indonesia (Jakarta. Buku Kompas, 2003) hlm. 146.

11 A. Hamid S. Attamini Peran Keputusan Presiden RI Dalam Penyelenggaraan Pemerintahan (Jakarta Disertasi FH.UI, 1990) hlm. 325. 
mentalitas penegak hukum; Fasilitas yang cukup atau kurang; Taraf kesadaran dan kepatuhan hukum warga masyarakat. ${ }^{12}$

Dalam implementasi produk Perda dapat menemui berbagai kendala. Sebagai fenomena umum, kendala dimaksud adanya kecenderungan dari mentalitas penegang hukum yaitu Satuan Polisi Pamong Praja (Satpol PP) yang membiarkan pelanggaran selalu terjadi. Di samping itu secara mendasar bahwa kesadaran hukum masyarakat masih kurang serta lebih mementingkan diri sendiri.

Adapun teori pemidanaan yang diselaraskan dengan Perda penerapan sanksi pidana, tidak lain adalah teori relatif (teori tujuan), berporos pada dua tujuan pemidanaan yaitu preventif dan deterrence. Hal ini dikemukakan oleh tokoh aliran klasik Jeremy Benthan yang dikutip oleh M Sholehuddin ${ }^{13}$ yaitu: Mencegah semua pelanggaran; Mencegah pelanggaran yang paling jahat; Menekan Kejahatan; Menekan kerugian/biaya sekecil-kecilnya.

Berkenaan dengan penerapan sanksi pidana dalam produk Perda, teori efektivitas sanksi negatif dari RD Schwartz dan S Orleans sebagaimana dikutip oleh Suryono Sukanto, dapat dipakai, dengan beberapa uraian sebagai berikut: ${ }^{14}$

a. Sanksi negatif (hukuman) mengurangi pelanggaran, baik yang dilakukan pelanggar maupun pihak-pihak lainnya;

b. Semakin keras sanksi negatif, semakin tinggi derajat efektivitasnya; c. Sanksi negatif dapat diterapkan tanpa mengakibatkan terjadinya kerugiankerugian;

d. Kemungkinan-kemungkinan lain tidak dapat dianggap sebagai suatu alternatif yang sederajat dengan penerapan sanksi negatif.

Khusus tentang sanksi pidana, menurut Supanto dalam Hukum Pidana untuk menangani perkara, yang penting adalah adanya sanksi pidana. Pelanggaran administrasi diselesaikan secara administratif, penyelesaian pidana secara materiel harus ada yang melanggar/ menyimpangi ketentuan hukum pidana, dan akan diberi sanksi pidana. ${ }^{15}$

\section{Pembentukan Peraturan Daerah}

Sesuai Undang-Undang Nomor 12 Tahun 2011, menurut Pasal 7 (1) jenis dan hirarki peraturan Perundang-undangan terdiri atas:

a. Undang-Undang Dasar Negara Republik Indonesia Tahun 1945;

b. Ketetapan Majelis Permusyawaratan Rakyat;

c. Undang-undang / Peraturan Pemerintah Pengganti Undang-Undang;

d. Peraturan Pemerintah;

e. Peraturan Presiden;

f. Peraturan daerah Provinsi; dan

g. Peraturan Daerah Kabupaten/Kota

Adapun materi muatan Perda menurut Undang-Undang Nomor 12 Tahun 2011 dinyatakan dalam, Pasal 14 materi muatan Peraturan Daerah Provinsi dan Peraturan Daerah Kabupaten/Kota berisi materi muatan dalam rangka penyelenggaraan otonomi daerah dan 
tugas pembantuan serta menampung kondisi khusus daerah dan/atau penjabaran lebih lanjut Peraturan Perundang-undangan yang lebih tinggi. Pada pasal 15 (1) materi muatan mengenai ketentuan pidana hanya dapat dimuat dalam a. Undang-Undang, b. Peraturan Daerah Provinsi, atau c. Peraturan Daerah Kabupaten/ Kota.

Sedangkan Pembentukan Perda, menurut Undang-Undang Nomor 23 Tahun 2014, antara lain sebagai berikut:

\section{Pasal 236}

(1) Untuk penyelenggaraan Otonomi Daerah dan Tugas Pembantuan, Daerah membentuk Perda.

(2) Perda sebagaimana dimaksud pada ayat (1) dibentuk oleh DPRD dengan persetujuan bersama kepala Daerah.

(3) Perda sebagaimana dimaksud pada ayat (1) memuat materi muatan:

a. Penyelenggaraan otonomi daerah dan tugas pembantuan; dan

b. Penjabaran lebih lanjut ketentuan peraturan perundang-undangan yang lebih tinggi.

(4) Selain materi muatan sebagaimana dimaksud pada ayat (3), Perda dapat memuat materi muatan lokal sesuai dengan ketentuan peraturan perundang-undangan.

\section{Pasal 237}

(1) Asas pembentukan dan materi muatan Perda berpedoman pada ketentuan peraturan perundang-undangan dan asas hukum yang tumbuh dan berkembang dalam masyarakat sepanjang tidak bertentangan dengan prinsip Negara Kesatuan Republik Indonesia.

(2) Pembentukan Perda mencakup tahapan perencanaan, penyusunan, pembahasan, penetapan, dan pengundangan an

berpedoman pada ketentuan perundangundangan.

(3) Masyarakat berhak memberikan masukan secara lisan dan/atau tertulis dalam pembentukan Perda.

(4) Pembentukan Perda sebagaimana dimaksud pada ayat (2) dilakukan secara efektif dan efisien.

\section{Pasal 238}

(1) Perda dapat memuat ketentuan tentang pembebanan biaya paksaan penegakan/ pelaksanaan Perda seluruhnya atau sebagian kepada pelanggar sesuai dengan ketentuan peraturan perundang-undangan.

(2) Perda dapat memuat ancaman pidana kurungan paling lama 6 (enam) bulan atau pidana denda paling banyak Rp.50.000.000,00 (lima puluh juta rupiah).

(3) Perda dapat memuat ancaman pidana kurungan atau pidana denda selain sebagaimana dimaksud pada ayat (2) sesuai dengan peraturan perundang-undangan.

(4) Selain sanksi sebagaimana dimaksud pada ayat (1), Perda dapat memuat ancaman sanksi yang bersifat mengembalikan pada keadaan semula dan sanksi administrarif.

(5) Sanksi administratif sebagaimana dimaksud pada ayat (4) berupa:
a. Teguran lisan;
b. Teguran tertulis;
c. Penghentian sementara kegiatan;
d. Penghentian tetap kegiatan;
e. Pencabutan sementara izin;
f. Pencabutan tetap izin;
g. Denda administratif; dan/atau
h. Sanksi administratif lain sesuai dengan ketentuan peraturan perundang- undangan.

Langkah awal penyusunan Perda, berupa Rancangan Peraturan Daerah (Raperda). Pada 
pasal 56 (2) Undang-Undang Nomor 12 Tahun 2011: "Rancangan Peraturan daerah Provinsi sebagaimana dimaksud pada ayat (1) disertai dengan penjelasan atau keterangan dan/atau Naskah Akademis". Sesuai Pasal 1 ayat (11) Naskah Akademik adalah naskah hasil penelitian atau pengkajian hokum dan hasil penelitian lainnya terhadap suatu masalah tertentu yang dapat dipertanggung jawabkan secara ilmiah mengenai pengaturan masalah tersebut dalam suatu rancangan undang-undang, rancangan peraturan daerah provinsi, atau rancangan peraturan daerah kabupaten/kota sebagai solusi permasalahan dan kebutuhan hukum masyarakat.

Pembuatan Naskah Akademis merupakan langkah awal yang tidak terpisahkan dalam pembentukan peraturan perundangundangan, termasuk dalam pembentukan Perda. Kedudukan hukum naskah akademis yang semula pada Undang-Undang Nomor 10 Tahun 2004 masih bersifat pilihan ataupun fakultatif, setelah diundangkannya UndangUndang Nomor 12 Tahun 2011, menjadi wajib. Walaupun dalam perkembangan yang ada, pada pembuatan RUU KUHP baru disusun naskah akademis perubahan KUHP setelah RUU KUHP selesai pada tahun 2011. Akhirnya naskah akademis RUU KUHP, dan RUU KUHP telah diserahkan kepada DPR Mei 2015.

Khusus untuk produk Naskah Akademis yang dibuat di Badan Pembinaan Hukum Nasional Kementerian Hukum dan Hak Asasi Manusia merupakan konsep dasar suatu RUU, dengan penjelasan secara akademis produk RUU yang dibuat, yang kemudian disertai dengan perumusan pasal demi pasal. Dalam perkembangan kemudian, melalui Peraturan Menteri Hukum dan Hak Asasi Manusia RI Nomor M.HH.01.PP.01.01 Tahun 2008 tentang Pedoman Penyusunan Naskah Akademik Rancangan Peraturan Perundang-undangan, pada pasal 1 ayat (1) Naskah Akademik adalah naskah yang dapat dipertanggungjawabkan secara ilmiah mengenaikonsepsi yang berisi latar belakang, tujuan penyusunan, tujuan yang ingin diwujudkan dan lingkup, jangkauan, obyek, atau arah pengaturan substansi rancangan peraturan perundang-undangan. (2) Penyusunan Naskah Akademik adalah pembuatan Naskah Akademik yang dilakukan melalui suatu proses secara cermat, komprehensif, dan sistematis.

Dalam praktik pembinaan dan pembangunan nasional, di Badan Pembinaan Hukum Nasional Kementerian Hukum dan Hak Asasi Manusia RI produk Naskah Akademis, diawali dengan suatu penelitian dan pengkajian hukum. Penelitian hukum merupakan suatu kegiatan ilmiah, yang didasarkan pada metode, sistemtika dan pemikiran tertentu, yang bertujuan untuk mempelajari satu atau beberapa gejala hukum tertentu, dengan jalan menganalisanya. Kecuali itu, maka juga diadakan pemeriksaan yang mendalam terhadapfakta hukum tertentu, untuk kemudian mengusahakan suatu pemecahan atas permasalahan permasalahan yang timbul di dalam gejala yang bersangkutan. ${ }^{16}$

Penelitian hukum dimulai dengan penelusuran terhadap bahan-bahan hukum sebagai dasar untuk membuat suatu keputusan hukum (legal decission making) terhadap kasuskasus hukum yang konkret. Pada sisi lainnya, penelitian hukum juga merupakan kegiatan hukum untuk memberikan refleksi dan penilaian

16 Soerjono Soekanto, Op.cit. hlm.43. 
terhadap keputusan-keputusan hukum yang telah dibuat terhadap kasus-kasus hukum yang pernah terjadi atau akan terjadi. ${ }^{17}$

Pengkajian hukum, sebagai produk asli sejak awal tahun 1980-an di Badan Pembinaan Hukum Nasional Kementerian Hukum dan Hak Asasi Manusia RI dalam implementasinya adalah sebagai kegiatan ilmiah yang didasarkan pada metode, sistematika, dan analisa tertentu, yang bertujuan untuk menjawab gejala hukum tertentu, dengan melibatkan secara mendalam disiplin hukum dan disiplin ilmu lainnya, serta pihak-pihak yang saling terkait, dengan memberikan rekomendasi atas gejala hukum dan permasalahan yang timbul.

Pembuatan Perda melibatkan jajaran DPRD dengan Pemerintah Daerah. Interaksi politik dan hukum dalam hal pembuatan Perda, dalam hal terdapat keterbatasan SDM pada DPRD dan Pemerintah Daerah, terkadang ditemui produk Perda diserahkan pada kalangan akademisi di berbagai Fakultas Hukum baik swasta maupun negeri. Di samping itu, Divisi Hukum pada Kantor Wilayah Kementerian Hukum dan Hak Asasi Manusia juga memberikan supervisi dan perbantuan untuk mendukung pembuatan Perda.

Sebagai negara hukum yang demokratis, aspirasi masyarakat terhadap berbagai aspek yang akan diatur dalam Perda, juga harus memperhatikan kepentingan masyarakat sendiri. Eksistensi lembaga perwakilan rakyat baik yang terwujud mulai DPRD Kabupaten/Kota, DPRD Provinsi, DPR dan DPD, dapat diartikan bahwa seluruh kepentingan masyarakat telah diserahkan secara total kepada perwakilannya. Warga masyarakat luas harus diberi tahu dan diberi kesempatan untuk mencermati produk peraturan yang akan dibuat. Karena pada gilirannya yang akan terkena baik secara langsung atau tidak langsung adalah warga masyarakat sendiri.

Beranjak dari hasil ini, pada pasal 92 ayat (1) Undang-Undang Nomor 12 Tahun 2011 dinyatakan: "Penyebarluasan Prolegda dilakukan oleh DPRD dan Pemerintah Daerah sejak penyusunan Prolegda, Penyusunan Rancangan Peraturan daerah, Pembahasan rancangan Peraturan daerah, hingga pengundangan Peraturan Daerah". Pada ayat (2): "Penyebarluasan sebagaimana dimaksud pada ayat (1) dilakukan untuk dapat memberikan informasi dan/atau memperoleh masukan masyarakat dan para pemangku kepentingan".

PakarHukum Administrasi Negara Universitas Airlangga Philipus M. Hadjon menyatakan bahwa: "Konsep partisipasi masyarakat berkaitan dengan konsep keterbukaan. Dalam artian, tanpa keterbukaan pemerintahan tidak mungkin masyarakat dapat melakukan peran serta dalam kegiatan-kegiatan pemerintahan". Keterbukaan baik openheid maupun openbaar "heid" sangat penting artinya bagi pelaksanaan pemerintahan yang baik dan demokratis. Dengan demikian, keterbukaan dipandang sebagai suatu asas ketatanegaraan mengenai pelaksanaan wewenang secara layak. ${ }^{18}$

Partisipasi masyarakat, hanya dapat tumbuh dan berkembang di negara demokratis. Ada semacam gugatan yang kurang mempercayai sistem demokrasi perwakilan yang diterapkan di banyak negara, termasuk Indonesia. Menurut Frans Magnis Suseno demokrasi perwakilan

17 Johny Ibrahim, Teori dan Metodologi Penelitian Hukum Normatif (Malang: Bayumedia, 2006), hlm. 299.

18 Philipus M. Hadjon, Perlindungan Hukum Bagi Rakyat di Indonesia (Surabaya: PT Bina Ilmu, 1987), hlm. 4-5. 
mempunyai dua kelemahan, yaitu, pertama, rakyat tidak langsung dapat membuat undangundang, melainkan melalui wakil-wakil yang mereka pilih. Keputusan-keputusan yang paling penting dalam kenyataannya diambil oleh beberapa orang saja. Maka dalam demokrasi perwakilan akan muncul unsur elitisme. Elitisme ini ditandai dengan terbatasnya implementasi asas keterbukaan dan akhirnya terbatas juga partisipasi masyarakat dalam proses pengambilan keputusan. Kedua, Demokrasi perwakilan dapat menjadi totaliter jika mayoritas rakyat memutlakkan kehendaknya, dan tidak menutup kemungkinan menjadi oligarkis jika minoritas memutlakkan kehendaknya terhadap mayoritas. ${ }^{19}$

Idealisme partisipasi publik dalam pengambilan kebijakan publik, perlu didukung oleh budaya politik yang berkembang di lingkungan masyarakat itu sendiri. Menurut Rusadi Kantaprawira, budaya politik tidak lain adalah pola tingkah laku individu dan orientasinya terhadap kehidupan politik yang dihayati oleh para anggota suatu sistem politik yang inheren (melekat) pada setiap masyarakat yang terdiri dari individu yang hidup, baik dalam sistem politik tradisional, transisional, maupun moderen. ${ }^{20}$

Sebagai negara hukum yang demokratis, secara implisit dan eksplisit seluruh produk peraturan perundang-undangan di Indonesia tidak boleh bertentangan dengan Pancasila dan UUD 1945. Dengan perkataan lain, sistem hukum Indonesia berasaskan Pancasila dan UUD 1945.
Hal itu dapat diukur secara universal oleh Fuller tentang delapan asas yang disebut principles of legality yang dikutip Satjipto Rahardjo, yaitu: ${ }^{21}$

1) Sistem hukum harus mengandung peraturan-peraturan, maksudnya ia tidak boleh mengandung sekedar keputusan yang bersifat ad hoc.

2) Peraturan yang telah dibuat itu harus diumumkan;

3) Tidak boleh ada peraturan yang berlaku surut, karena apabila yang demikian itu tidak ditolak, maka peraturan itu tidak bisa dipakai untuk menjadi pedoman tingkah laku. Membolehkan peraturan secara berlaku surut berarti merusak integrasi peraturan yang ditujukan untuk berlaku bagi waktu yang akan datang;

4) Peraturan harus disusun dalam rmusan bahasa baku, bahasa yang dapat dimengerti oleh masyarakat;

5) Sistem tidak boleh mengandung peraturan yang bertentangan satu sama lain.

6) Peraturan tidak boleh mengandung tuntutan yang melebihi apa yang dapat dilakukan;

7) Tidak boleh ada kebiasaan untuk sering mengubah-ubah peraturan sehingga menyebabkan seseorang akan kehilangan orientasi;

8) Harus ada kecocokan antara peraturan yang diundangkan dengan pelaksanaannya sehari-hari.

Kesiapan daerah untuk membentuk Perda di Kabupaten/Kota, dan provinsi, juga banyak terkendala, dan tentu saja pada daerah 
pemekaran yang baru dibentuk. Demikian pula halnya dengan keterkaitannya dengan pelaksanaan otonomi khusus di Papua, sebagaimana dikemukakan oleh Barnabas Suebu yaitu: "Masih banyaknya peraturan pelaksanaan Undang-Undang Nomor 21 Tahun 2011 dalam bentuk peraturan daerah provinsi (Perdasi) maupun peraturan khusus (Perdasus) yang belum disusun. ${ }^{22}$ Dalam enam tahun pertama implementasi otonomi khusus di Papua, perangkat hukum dalam bentuk Perdasi dan Perdasus yang sudah dirumuskan dan ditetapkan hanya 4 Perdasi, sementara Undang-Undang Otonomi Khusus Papua mengamanatkan pembuatan 17 Perdasi dan 11 Perdasus". 23

Menurut Hari Sabarno, mantan Menteri Dalam Negeri 2001-2004 menyatakan: “Dalam prakteknya pembentukan Peraturan Daerah cenderung mengabaikan sistem hukum nasional dan menerapkan jenis dan bentuk materi muatan yang berbeda-beda berdasarkan kebutuhan dan kepentingan daerah sendiri. Di samping itu, pembentukan peraturan daerah tidak sesuai dengan tujuan, situasi dan kondisi nasional, sehingga kadangkala menimbulkan pertentangan dengan ketentuan diatasnya. ${ }^{24}$

Pembentukan Perda sebagaimana mengacu pada peraturan perundang-undangan yang pernah berlaku sejak reformasi 1999 sampai dengan undang-undang Nomor 23 Tahun 2014, yang didalamnya ada fungsi-fungsi, dan represif, sebagai perwujudan The Interaction Model. Model hubungan antara pemerintah pusat dan daerah secara teoritis menurut Clarke dan Stewart, dapat dibedakan menjadi: ${ }^{25}$

Pertama, The Relative Authonomy Model, memberikan kebebasan yang relatif besar kepada pemerintah daerah dengan tetap menghormati eksistensi pemerintah pusat. Penekanannya adalah pada kebebasan bertindak bagi pemerintah daerah dalam rangka kekuasaan/tugas dan tanggung jawab yang telah dirumuskan oleh peraturan perundangundangan.

Kedua, The Agency Model. Model dimana pemerintah daerah tidak mempunyai kekuasaan yang cukup berat sehingga keberadaannya terlihat sebagai agen pemerintah pusat yang bertugas untuk menjalankan kebijaksanaan pemerintah pusatnya. Pada model ini berbagai petunjuk rinci dalam peraturan perundangundangan sebagai meksnisme kontrol sangat menonjol. Pada model ini pendapatan asli daerah bukanlah hal yang penting dan system keuangan daerahnya didominasi oleh bantuan dari pemerintah pusat.

Ketiga, The Interaction Model. Merupakan suatu bentuk model dimana kebebasan dan peran pemerintah daerah ditentukan oleh interaksi yang terjadi antara pemerintahpusat dan pemerintah daerah.

Dalam artian eksistensi negara, kewenangan Pemda dan DPRD dalam membuat Perda, disamping secara langsung diwakili oleh pemerintah pusat, juga diwakili oleh warga masyarakatnya.

\footnotetext{
22 Muhadam Labolo. Desentralisasi Asimetrik di Indonesia. Peluang, Tantangan dan Recovery (Jakarta: Wadi Press 2014). hlm.132).

3 Ibid, hlm.173.

24 Hari Sabarno, Memandu Otonomi Daerah Menjaga Kesatuan Bangsa (Jakarta: Sinar Grafika, 2007), hlm. 197.

25 Ni'matul Huda, Pengawasan Pusat Terhadap Daerah Dalam Penyelenggaraan Pemerintahan Daerah (Yogyakarta, FH UII Pers, 2007), hlm. 1-2.
} 
Pentingnya ranah publik (public sphere) dalam pengawasan seperti dikatakan oleh Jurgen Habermas, bahwa negara yang secara organisasi mempunyai wewenang yang sangat besar dalam membuat dan melaksanakan kebijaksanaannya akan dikontrol oleh elemen yang sebenarnya merupakan pemilik sah suatu negara tersebut. ${ }^{26}$

\section{Sanksi Pidana}

\section{a. Pembentukan}

Sesuai pasal 238 Undang-undang Nomor 23 Tahun 2014 dalam produk Perda, ancaman pidana kurungan atau sanksi denda, sanksi yang bersifat mengembalikan pada keadaan semula, dan sanksi administratif". Fenomena pencantuman sanksi pidana pada Perda, di samping untuk menegakkan efektivitas Perda yang dibuat, juga disesuaikan dengan keselarasan dan proporsionalitas bahwa pelanggar Perda dapat/layak diberi sanksi pidana.

Menurut Pasal 10 KUHP, Pidana terdiri atas: Pidana Pokok yang terdiri dari Pidana mati; Pidana penjara; Pidana kurungan; Pidana denda; Pidana tutupan. Dan Pidana Tambahan, yang terdiri dari Pencabutan hak-hak tertentu; Perampasan barang-barang tertentu; Pengumuman putusan hakim. ${ }^{27}$

Pembentukan Perda oleh Pemerintah Daerah dan DPRD, yang mencantumkan ancaman pidana kurungan atau denda merupakan kebijakan kriminalisasi. Menurut Barda Nawawi Arief, proses kriminalisasi harus memperhatikan berbagai aspek, yaitu: ${ }^{28}$
1) Penggunaan hukum pidana harus mempergunakan tujuan pembangunan nasional, yaitu mewujudkan masyarakat adil dan makmur yang merata material dan sepiritual berdasarkan Pancasila.

2) Perbuatan yang diusahakan untuk dicegah atau ditanggulangi dengan hukum pidana harus merupakan perbuatan yang tidak dikehendaki, yaitu perbuatan yang mendatangkan kerugian (material dan atau spiritual) atas warga masyarakat;

3) Penggunaan hukum pidana harus pula memperhitungkan prinsip biaya dan hasil (cost and benefid principles) juga sosial cost atau biaya sosial;

4) Penggunaan hukum pidana harus pula memperhatikan kapasitas atau kemampuan daya kerja dari badan-badan penegak hukum, yaitu jangan smapai ada kelampauan beban tugas (overbelasting).

Dalam hukum pidana positif di Indonesia, legislator memberikan peluang dan kebebasan yang relatif kepada hakim untuk memiliki jenis pidana, berat dan ringannya pidana dan cara bagaimana pidana tersebut akan dilaksanakan. Dalam hal jenis sanksi pidana, peluang dan kebebasan hakim untuk memilih bentuk sanksi yang dikehendakinya, teridentifikasi dari pencantuman sanksi pidana yang menggunakan baik sistem alternatif maupun kumulatif di dalam perundang-undangan pidana positif. Perumusan jenis sanksi pidana dalam KUHP pada umumnya memakai dua pilihan, misalnya

Imam Anshori Saleh, Konsep Pengawasan Kehakiman. Upaya Memperkuat Kewenangan Konstitusional Komisi Yudisial dalam Pengawasan Peradilan (Malang: Setara Pers, 2014), hlm. 244..

27 KUHP \& KUHAP Beserta Penjelasannya (Bandung: Citra Umbara, 2009). hlm. 5..

28 Barda Nawawi Arief, Bunga Rampai Kebijakan Hukum Pidana (Bandung: PT Citra Aditya Bakti, 1986), hlm. 33-34. 
"pidana penjara" atau "denda" (sistem alternatif). ${ }^{29}$

Pembentukan Perda yang di dalamnya ditetapkan sanksi pidana, di dalam negara hukum yang demokratis sesungguhnya merupakan detterent factor (faktor pencegah) agar warga masyarakat dapat lebih mengerti bahwa pelanggaran terhadap Perda pun, dapat dipidana. Sanksi pidana dalam Perda merupakan sanksi yang ringan, dan secara implisit hakim dapat bahkan wajib memilih bentuk sanksi yang memenuhi rasa keadilan masyarakat.

Jika dikorelasikan dengan tujuan pemidanaan dalam perkembangan yang ada, menurut Muladi, tujuan pemidanaan adalah untuk memperbaiki kerusakan individu dan sosial (individual dan social damages) yang diakibatkan oleh tindak pidana. Hal ini terdiri dari seperangkat tujuan pemidanaan yang harus dipenuhi, dengan catatan, bahwa tujuan manakan yang merupakan tidak berat sifatnya kasusistis. Perangkat tujuan pemidanaan yang dimaksudkan diatas adalah (1) pencegahan (umum dan khusus), (2) perlindungan masyarakat, (3) memelihara solidaritas masyarakat, (4) pengimbalan/pengimbangan. Istilah ini digunakan oleh Soedarto yang dalam hal ini mengatakan bahwa "vergellen" bukannya membahas atau membalas dendam, tetapi pengimbalan atau pengimbangan. ${ }^{30}$

\section{b. Penerapan}

Penetapan sanksi pidana dalam Perda, secara mendasar sangat dimungkinkan, dan mengacu pada peraturan perundang-undangan tentang pemerintahan daerah. Terakhir, juga dimungkinkan menurut Undang-Undang Nomor 23 Tahun 2014. Sebelum dibentuknya UndangUndang Nomor 23 Tahun 2014 tersebut, yaitu Undang-Undang Nomor 22 Tahun 1999, dan Undang-Undang Nomor 32 Tahun 2004, Perda yang didalamnya terdapat sanksi pidana biasanya menyangkut Perda Tentang Kebersihan, Perda Tentang Kebersihan Umum, Perda Tentang ljin Mendirikan bangunan, dan terkadang Perda yang Berisi pungutan (pajak).

Penerapan atau implementasi Perda yang berupa pungutan, misalnya PBB, Pajak kendaraan Bermotor, Perizinan, dan Parkir, biasanya dapat berlangsung sesuai yang diharapkan. Warga masyarakat sadar dan terpanggil kewajibannya dalam membayar pajak. Dan aparatur pemerintah daerah, baik yang melakukan kerjasama dengan bank dan kelompok warga masyarakat yang memenuhi syarat, selalu siap sedia menerima pembayaran pajak.

Pada Perda yang lain, misalnya kebersihan, ketertiban umum dan keamanan masyarakat, dan ijin mendirikan bangunan, larangan merokok di tempat umum, dan banyak terjadi di wilayah hukum indonesia, pada umumnya perdaperda tersebut tidak diimplentasikan dengan baik. banyak kendala yang menghadang, dan Satuan Polisi Pamong Praja, yang ditugasi untuk menegakkan Perda di kabupaten/Kota tertentu ataupun Satuan Polisi Pamong Praja Provinsi yang ditugasi menegakkan Perda Provinsi tertentu, seringkali tidak berdaya ataupun justru membiarkan pelanggaran terhadap Perda. Dan kalaupun harus menegakkan Perda, yang berpotensi timbulnya perlawanan keberatan

29 M. Sholehuddin, Opcit. HIm. 189.

30 Muladi, Lembaga Pidana Bersyarat (Bandung: Alumni, 2004), hlm. 61. 
dari warga masyarakat, pada gilirannya mereka sudah didukung oleh Polri dan TNI.

\section{Implementasi Penggunaan Sanksi Pidana di dalam Peraturan Daerah}

Pemerintahan daerah Kabupaten/Kota. Dan Provinsi yang tersebar di seluruh Wilayah Indonesia, sangat menikmati kebijakan negara tentang otonomi daerah serta otonomi khusus di Aceh, Papua, dan Yogyakarta. Pendapatan daerah, potensi daerah, sarana dan prasarana, ekonomi daerah, serta sumber daya manusia, serta profesionalisme anggota DPRD yang secara minimal berpendidikan SLTA, dan jajaran pemerintah daerah sendiri, tentu tidak sama.

Terdapat daerah yang sangat maju ekonominya dan sangat menjanjikan, SDM, baik warga masyarakat termasuk anggota DPRD, dan jajaran pemerintah daerah profesional. Namun sebaliknya tidak sedikit daerah lain, banyak diwarnai keterbatasan dan kekurangan di banyak hal. Dalam produk pembentukan Perda juga terkendala, termasuk dalam implementasinya. Pada gilirannya, jika terdapat pembentukan Perda, tidak jarang mencari jalan pintas meng-copy Perda dari Kabupaten/Kota lainnya, yang sudah sukses dilaksanakan tanpa melihat kondisi senyatanya daerah/kota yang meng-copy Perda tersebut.

Dengan dilatarbelakangi keberadaan masyarakat, adat istiadat, cara pandang, sarana dan prasarana, dan perekonomian, agama, serta iklim yang berbeda-beda, mengcopy Perda di daerah lain untuk diterapkan di Kabupaten/ Kota bahkan Provinsi yang berbeda, tentu dapat menimbulkan permasalahan. Secara minimal, Perda tersebut tidak dapat diterapkan.
Pada periode 2010 s/d 2013, dinamika Perda bermasalah adalah sebagai berikut: ${ }^{31}$ Perda bermasalah tahun 2010: Perda masuk 3000, bermasalah 407; Perda bermasalah tahun 2011: Perda masuk 9000, bermasalah 351; Perda bermasalah tahun 2012: Perda masuk 3000, bermasalah 173; Perda bermasalah tahun 2013: Perda masuk 2500, bermasalah 215.

Sebanyak 255 Perda bermasalah dari Januari - Oktober 2014 yang ditanda tangani Menteri Dalam negeri Gamawan Fauzi dan sebanyak 100 Perda bermasalah dari November - Desember 2014 yang ditanda tangani Menteri Dalam Negeri Tjahyo Kumolo, dengan total jumlah Perda bermasalah yang sudah diklasifikasi melalui Surat Menteri Dalam Negeri sampai 2014 sebanyak 355 Perda. Perda bermasalah yang dibatalkan paling banyak berkaitan dengan pajak dan/retribusi-retribusi, selebihnya terkait diskriminasi. Kementerian Dalam Negeri mempersiapkan Elektronik Peraturan daerah (e-Perda) untuk meminimalisasi banyak Perda bermasalah.

Penerapan sanksi, termasuk sanksi pidana dalam Perda sangat jarang terjadi. Pembiaran oleh pemerintah daerah kabupaten/kota, dan provinsi terhadap pelanggaran Perda merupakan fenomena umum. Satuan Polisi Pamong Praja tidak berdaya untuk melakukan penegakan hukum terhadap pelanggaran yang bersifat massal. Pada gilirannya, Polri harus memperkuat penegakan hukum yang dalam kasus-kasus tertentu, justru dibantu lagi oleh TNI.

Sebagai gambaran umum, sarana dan prasarana dalam penegakan hukum Perda, serta sarana dan prasarana yang yang dibuat oleh

1 Koran Sindo, "Pragmatisme Picu Perda Bermasalah”. (Senin, 31 Agustus 2015), hlm.2. 
pemerintah daerah kabupaten/kota setempat., agar tidak terjadi pelanggaran terhadap Perda, juga kurang bahkan tidak ada. Taraf kesadaran hukum masyarakat untuk mematuhi Perda, juga terbatas. Dengan berbagai alasan dari yang rasional sampai irrasional, mereka tidak merasa melanggar Perda.

Permintaan bantuan dari Pemerintah daerah Kabupaten/Kota, Provinsi pada Polri untuk menegakkan Perda, menurut Farouk Muhammad" 32 "Dengan mekanisme yang telah disepakati bersama, kepala daerah bahkan dapat menggunakan dan/atau memegang pimpinan atas Kepolisian dalam rangka menegakkan keamanan dan/atau peraturan daerah".

Berkaitan dan berkenaan tentang peran, tugas dan wewenang Polri dalam mendukung penegakan Perda, yang terjadi di indonesia, antara lain: ${ }^{33}$

1) Kepolisian Negara Republik Indonesia merupakan alat negara yang berperan dalam memelihara keamanan dan ketertiban masyarakat, menegakkan hukum, memberi pengayoman dan pelayanan kepada masyarakat;

2) Kepolisian Negara Republik Indonesia merupakan lembaga pemerintah yang mempunyai tugas pokok menegakkan hukum, ketertiban umum, dan memelihara keamanan dalam negeri;

3) Fungsi Kepolisian Negara Republik Indonesia adalah salah satu fungi pemerintahan negara di bidang pemeliharaan keamanan dan ketertiban masyarakat, penegakan huku, perlindungan, pengayoman, dan pelayanan kepada masyarakat.
4) Kepolisian Negara Republik Indonesia berkedudukan langsung di bawah Presiden.

Dalam implementasi sanksi pidana yang terdapat pada Polri, model pemidanaan biasanya berupa denda, dan angka nominalnya masih dapat dijangkau oleh para pelanggarnya. Memang terdapat juga fungsi pembinaan para pelanggar Perda ada yang ditempatkan di Dinas Sosial, seperti model diasramakan dalam waktu tertentu. Dan yang paling banyak terjadi, para pelanggar Perda, langsung dibebaskan setelah diberi teguran dan pengarahan agar tidak mengulangi perbuatannya.

\section{Penutup}

Dari berbagai uraian di atas, dapat ditarik suatu kesimpulan bahwa pembentukan Perda di tengah kompleksitas kehidupan masyarakat, dan berbagai keterbatasan di seluruh wilayah hukum kabupaten/kota dan provinsi di Indonesia, bukan pekerjaan yang mudah. Sumber daya manusia jajaran DPRD, sumber daya manusia jajaran pemerintah daerah kabupaten/Kota, Provinsi, interaksi politik, dan harus patuh pada rambu-rambu di dalam negara hukum yang demokratis, serta ke-Indonesia-an, sangat memerlukan keseriusan dan pemahaman yang mendalam bagi kesejahteraan masyarakat. Sejak awal, warga masyarakat harus didengar, mulai pembentukan Raperda termasuk adanya penetapan sanksi pidana, Pembahasan di DPRD, Pengundangan Perda, serta sosialisasi yang intensif dengan cara-cara kekeluargaan, masih sangat terbatas.

Beranjak dari kesimpulan tersebut dapat diberikan suatu saran atau rekomendasi

32 Farouk Muhammad, Menuju Reformasi Polri (Jakarta: PTIK Pers \& CV Restu Agung, 2003), hlm. 72.

33 Sadjijono, Fungsi Kepolisian Dalam Pelaksanaan Good Governance (Yogyakarta: Laksbang 2010), hlm. 246. 
bahwa penegakan Perda dengan mengimplementasikan sanksi pidana bagi para pelanggarnya, merupakan pilihan terakhir yang harus dilaksanakan. Pilihan tersebut, tidak serta merta dapat dilaksanakan. Penerapan sanksi pidana sebagai ultimum remedium pada pelanggar Perda, utamanya pidana kurungan harus dihindari, selama da pilihan-pilihan lain yang dapat dimungkinkan oleh Perda itu sendiri yaitu pidana denda. Sebagai negara hukum yang demokratis dengan prinsip-prinsip kekeluargaan, selalu ada jalan tengah yang baik dan positif dalam menegakkan pelanggaran terhadap Perda. Strategi persuasif, preventif, akomodatif, dan simpatik dalam penegakan Perda, dapat menghindari konflik antara petugas dengan warga masyarakat yang melanggar. Permintaan bantuan untuk menegakkan keamanan dan ketertiban pada Polri, adalah sangat wajar. Namun permintaan bantuan pada TNI, harus dilihat sebagai upaya untuk menghindari konflik kekerasan antara Satpol PP bersama Polri, dengan warga masyarakat dan pendukungnya pelanggar Perda.

\section{Daftar Pustaka}

\section{Buku}

Arief, Barda Nawawi, Bunga Rampai Kebijakan Hukum Pidana (Bandung: PT Citra Aditya Bakti; 1986)

Attamini S, A Hamid, Peran Keputusan Presiden RI Dalam Penyelenggaraan Pemerintahan (Jakarta: Disertasi Fakultas Hukum Universitas Indonesia, 1990)

Hadjon M.,Philipus, Perlindungan Hukum Bagi Rakyat Indonesia (Surabaya: Bina IImu, 1987)

Handoyo, B. Hestu Cipto, Prinsip-prinsip Legal Drafting \& Desain Naskah Akademik Edisi Reisi (Yogakarta: Cahaya Atma Pustaka, 2014)

Hendratno, Edie Toet, Negara Kesatuan, Desentrealisasi dan Federalisme, (Yogyakarta: Graha IImu, 2009)
Huda, Ni'matul, Pengawasan Pusat Terhadap Daerah Dalam Rangka Penyelenggaraan Pemerintahan Daerah (Yogyakarta: FH UII Press, 2007)

Ibrahim, Anis, Legislasi dan Demokrasi. Interaksidan Konfigurasi Politik Hukum dalam Pembentukan Hukum di Daerah (Malang: In Trans Publishing 2008).

Ibrahim, Johny, Teori dan Metodologi Penelitian Hukum Normatif (Malang: Bayu Media, 2006).

Imam Anshori, Soleh, Konsep Pengawasan Kehakiman upaya memperkuat Kewenangan Konstitusional Komisi Yudisial Dalam Pengawasan Peradilan (Malang: Setara Pers, 2014)

Jazim, Hamidi dan Kemilau Mutik, Legislatif Drafting (Yogyakarta: Total Media, 2011)

Labolo, Muhadan, Desentralisasi Asimetrik dl Indonesia. Peluang, Tantangan dan Recovery (Jakarta: WADI Press, 2014)

Muhammad Farouk, Menuju Refortmasi Polri (Jakarta: PTIK Pers \& CV Restu Agung, 2002)

Muladi, Lembaga Pidana Bersyarat (Bandung: Alumni, 2004)

Prasetyo, Teguh, Kriminalisasi Dalam Hukum Pidana (Bandung: Nusa Media, 2010)

Rahardjo, Satjipto, Sisi-sisi Lain Hukum di Indonesia (Jakarta: Buku Kompas, 2003)

Sabarno, Hari, Memandu Otonomi daerah Menjaga Kesatuan Bangsa (Jakarta: Sinar Grafika, 2007)

Sadjijono, Fungsi Kepolisian Dalam Pelaksanaan Good Governance (Yogyakarta: Laksbang, 2010)

Sholehuddin, M, Sistem Sanksi Dalam Hukum Pidana. Ide Dasar Double Track System \& Implementasinya (Jakarta: Rajawali Pers, 2007)

Soekanto, Soerjono, Kesadaran Hukum dan Kepatuhan Hukum (Jakarta: Rajawali Pers, 1982)

Soekanto, Soerjono, Pengantar Penelitian Hukum (Jakarta: UI Pers, 1982)

Supanto, Kejahatan Ekonomi Global dan Kebijakan Hukum Pidana (Bandung: Alumni, 2010)

Suseno, Franz Magnis, Etika Politik Prinsip-prinsip Moral Dasar Kenegaraan Moderen (Jakarta: Gramedia Pustaka Utama, 1990)

Zainudin, Ali, Filsafat Hukum (Jakarta: Sinar Grafika, 2006)

\section{Makalah/Artikel/Prosiding/Hasil Penelitian}

Koran Sindo, "Pragmatisme Picu Perda Bermasalah" (Senin, 31 Agustus 2015) 


\section{Peraturan}

Kitab Undang-Undang Hukum Pidana

Undang-Undang Nomor 22 Tahun 1999 tentang Pemerintahan Daerah

Undang-Undang Nomor 21 Tahun 2001 tentang Otonomi Khusus Papua

Undang-Undang Nomor 2 tahun 2002 tentang Kepolisian Negara Republik Indonesia

Undang-Undang Nomor 32 Tahun 2004 tentang Pemerintahan Daerah
Undang-Undang Nomor 34 Tahun 2004 tentang Tentara Nasional Indonesia

Undang-Undang Nomor 11 Tahun 2006 tentang Pemerintahan Aceh

Undang-Undang Nomor 12 Tahun 2011 tentang Pembentukan Peraturan Perundang-undangan.

Undang-Undang Nomor 13 Tahun 2012 tentang Keistimewaan Daerah Istimewa Yogyakarta.

Undang-undang Nomor 23 Tahun 2014 tentang Pemerintahan Daerah 